\title{
Evaluation of the Pozzolanic Activity of Sewage Sludge Ash
}

\author{
M. A. Tantawy, A. M. El-Roudi, Elham M. Abdalla, and M. A. Abdelzaher \\ Department of Chemistry, Faculty of Science, Minia University, Minia 61519, Egypt
}

Correspondence should be addressed to M. A. Tantawy, matantawy75@yahoo.com

Received 22 May 2012; Accepted 18 July 2012

Academic Editors: M. Assael, A. Gil, and A. M. Seayad

Copyright () 2012 M. A. Tantawy et al. This is an open access article distributed under the Creative Commons Attribution License, which permits unrestricted use, distribution, and reproduction in any medium, provided the original work is properly cited.

\begin{abstract}
Raw sewage sludge was characterized by XRD, FTIR, SEM, and TGA techniques and incinerated in temperature range $650-950^{\circ} \mathrm{C}$ for $2 \mathrm{~h}$. The effect of incineration temperature on the microstructure and pozzolanic activity of the resultant ash was investigated by techniques mentioned above as well as Chapelle test. It was concluded that incineration of sewage sludge affects the microstructure and pozzolanic activity of the resultant ash. During incineration at temperatures lower than $800^{\circ} \mathrm{C}$, amorphous silica captures fixed carbon resulting from incomplete combustion conditions whereas at higher temperatures crystallization of amorphous silica was enhanced. Hydration products formed from hydrothermal treatment of silica fume with lime is amorphous whereas that of sewage sludge ash is fibrous. Hence, incineration of sewage sludge ash must be optimized at $800^{\circ} \mathrm{C}$ to preserve the pozzolanic activity of the resultant ash.
\end{abstract}

\section{Introduction}

Sewage is the collection of wastewater effluents from domestic, hospital, commercial, industrial establishments, and rain water. The objective of sewage treatment is to produce treated sewage water and sewage sludge suitable for safe discharge into the environment or reuse [1]. The most common treatment options for sewage sludge include anaerobic digestion, aerobic digestion, and composting. Choice of the treatment method depends on the amount of sludge and other sitespecific conditions [2]. Sewage sludge tends to accumulate heavy metals existing in the wastewater. The composition of sewage sludge and its content of heavy metals vary widely depending on the sludge origins and treatment options [3]. In past decades, sewage sludge was primarily disposed to landfills and seawaters [4]. Space limitations on existing landfills and increasing environmental concerns such as groundwater pollution from landfill leachate, odor emission and soil contamination have prompted the investigation of alternative disposal routes [5]. Sewage sludge has been used in agriculture as fertilizer and soil amendment [6]. However heavy metals such as $\mathrm{Zn}, \mathrm{Cu}, \mathrm{Ni}, \mathrm{Cd}, \mathrm{Pb}, \mathrm{Hg}$, and $\mathrm{Cr}$ are principal elements restricting the use of sludge for agricultural purposes [3]. The solidification/stabilization of sewage sludge in cementitious matrix has been evaluated [7]. Sewage sludge adversely affects durability of concrete, mainly due to the organic material which retards setting and heavy metals which interfere with the hardening reactions [8]. Hence, sewage sludge addition in concrete was limited to $10 \mathrm{wt} . \%$ and the solidified concrete was recommended for use in certain very specific applications [9]. Sewage sludge also has been used in production of clay bricks [10].

Application of sewage sludge without appropriate management might have adverse impacts on human health and the environment [11]. Legislative barriers for sewage sludge disposal options make incineration is the most attractive disposal method [12]. The advantages of sewage sludge incineration summarized as follows:

(i) large reduction of sludge volume by about $90 \%$ [13],

(ii) thermal destruction of toxic organic compounds [14],

(iii) recovery of much of the energy in the sewage sludge [15],

(iv) minimization of odor emission,

(v) making further management of sludge ash an easier task.

Sewage sludge ash has been used as an additive in production of construction materials [16], mortars [17], concrete [18], brick [19], asphalt paving mixes [20], aerated 


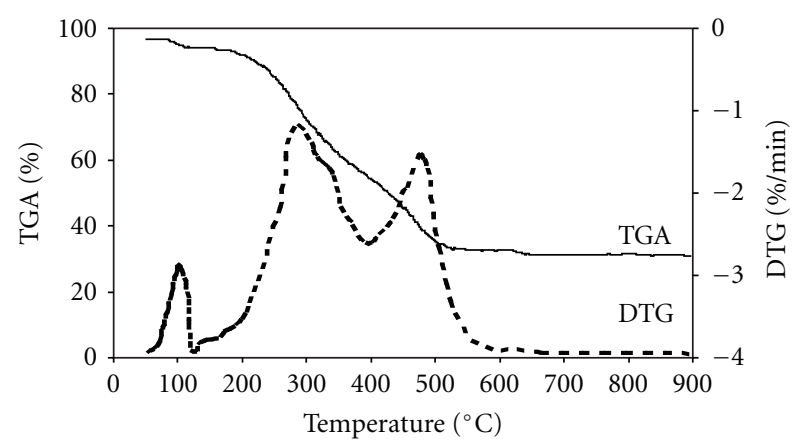

FIgURE 1: The TGA and DTG thermograms of raw sewage sludge.

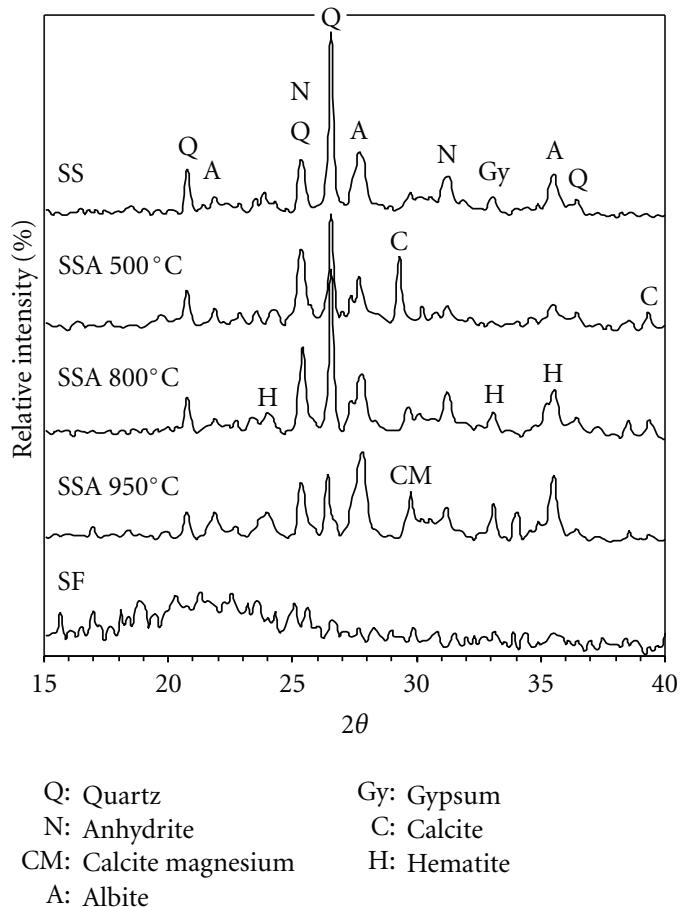

FIgURE 2: The XRD patterns of silica fume, raw sewage sludge, and sewage sludge incinerated at $500-950^{\circ} \mathrm{C}$.

concrete [21], lightweight and heat-insulating material [22], ceramic tiles [23], ecocement [24], and for soil stabilization [25]. Attention must be paid to the environmental impacts of sewage sludge ash when it is reused. Principal characteristics must be taken into account to use sewage sludge ash correctly in cement-based materials [26]. It was concluded that the leaching toxicity of sewage sludge ash blended cement is far lower than that of the national standards and minimum harmful matters can be contained and released in the environment [27]. Even sewage sludge ash containing high sulphate content is found to be compatible with cements with high $\mathrm{C}_{3} \mathrm{~A}$ content as binder in mortars [28].

Few researchers have indicated that sewage sludge ash has high pozzolanic activity and improves the workability and compressive strength of concrete [29]. On contrast, many researchers have shown that sewage sludge ash has low pozzolanic activity [30] and reduces the workability and

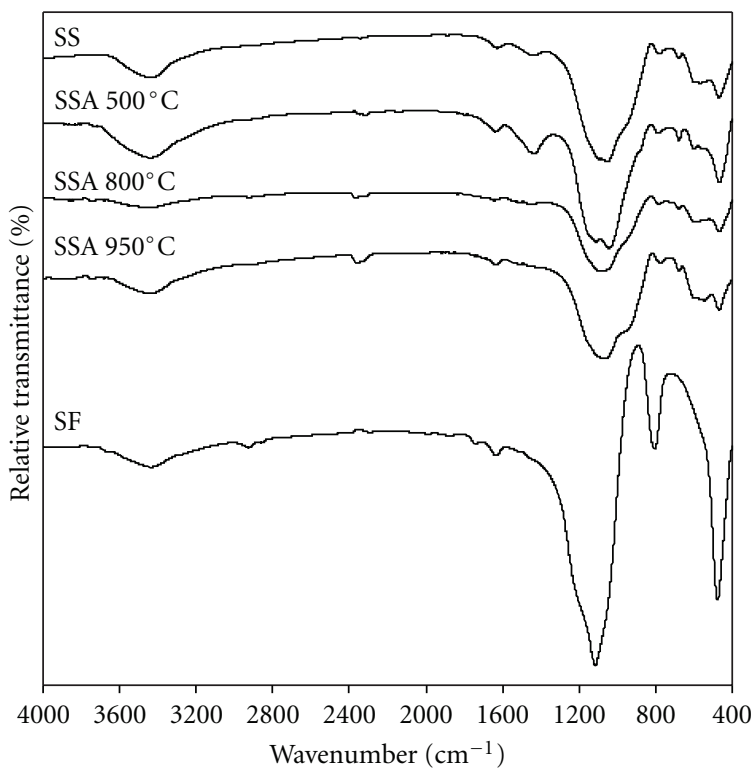

FIgUre 3: The FTIR spectra of silica fume, raw sewage sludge, and sewage sludge incinerated at $500-950^{\circ} \mathrm{C}$.

compressive strength of cementitious materials [31]. Incineration of sewage sludge at $600-1000^{\circ} \mathrm{C}$ greatly affects the chemical composition of the resultant ash [32]. Accordingly, the pozzolanic activity depends on the incineration temperature. Hence, incineration of sewage sludge at different temperatures such as $700^{\circ} \mathrm{C}$ [33], $800^{\circ} \mathrm{C}$ [34], or $850^{\circ} \mathrm{C}$ [26] may lead to the formation of high [35], moderate [36], or less [37] reactive sewage sludge ash and as a result enhances or reduces the workability of cementitious material. Hence, the aim of this study is to clarify the effect of incineration temperature on the microstructure and pozzolanicity of sewage sludge ash.

\section{Materials and Experimental Techniques}

Raw materials used in this study were raw sewage sludge from wastewater treatment facility in Minia Governorate, Egypt and silica fume from the Ferrosilicon Company, Edfo, Egypt. Raw sewage sludge was incinerated in an electrical muffle furnace with a heating rate $10^{\circ} \mathrm{C} / \mathrm{min}$ at $500-950^{\circ} \mathrm{C}$ for $2 \mathrm{hrs}$, recharged from the muffle furnace, cooled to room temperature in desiccator, and ground to pass $90 \mu \mathrm{m}$ sieve. $\mathrm{CaO}$ was prepared from pure $\mathrm{CaCO}_{3}$ natural powder after incineration at $1000^{\circ} \mathrm{C}$, ground and stored in tightly closed plastic bag to avoid carbonation. The pozzolanic activity of incinerated sewage sludge ash and silica fume was evaluated according to Chapelle test. One gram both of sample and $\mathrm{CaO}$ were added in $200 \mathrm{~mL}$ of distilled water. The mixture was hydrothermally treated at $100^{\circ} \mathrm{C}$ for $16 \mathrm{~h}$ in a stainless steel capsule of $350 \mathrm{~mL}$ maximum capacity. Then, the solution was filtrated and the residue was dried. The solution was titrated with $0.1 \mathrm{~N} \mathrm{HCl}$ solution using phenolphthalein as indicator. Fixed lime content (mmole/L) was calculated from the difference between the amount of 


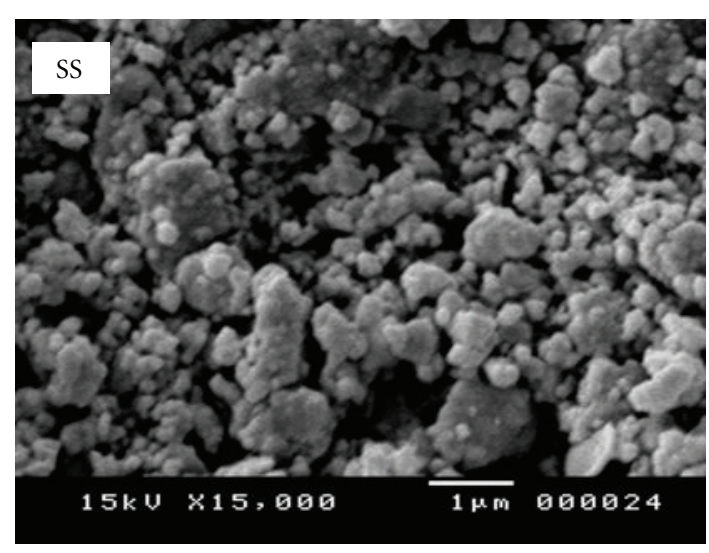

(a)

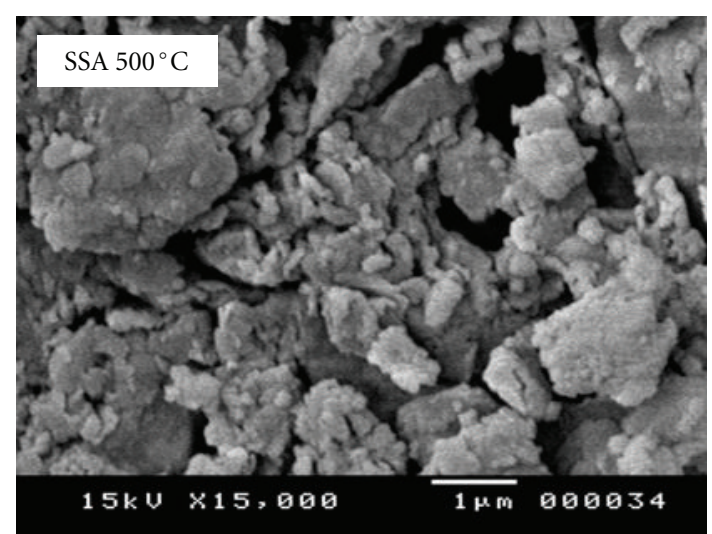

(c)

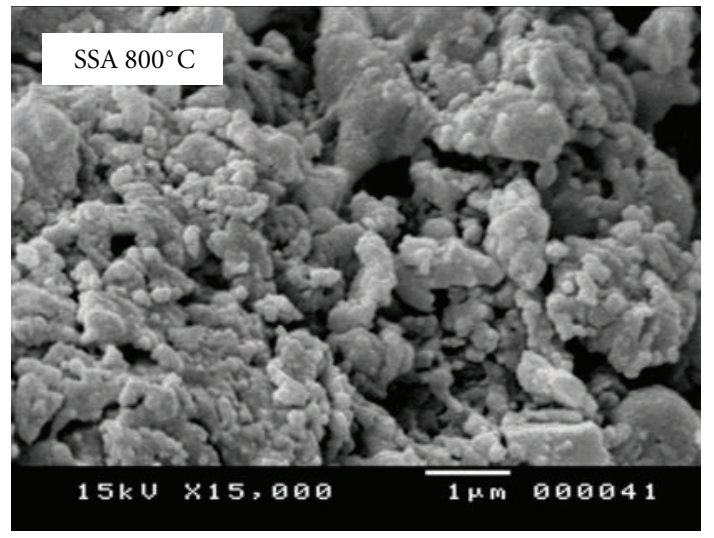

(b)

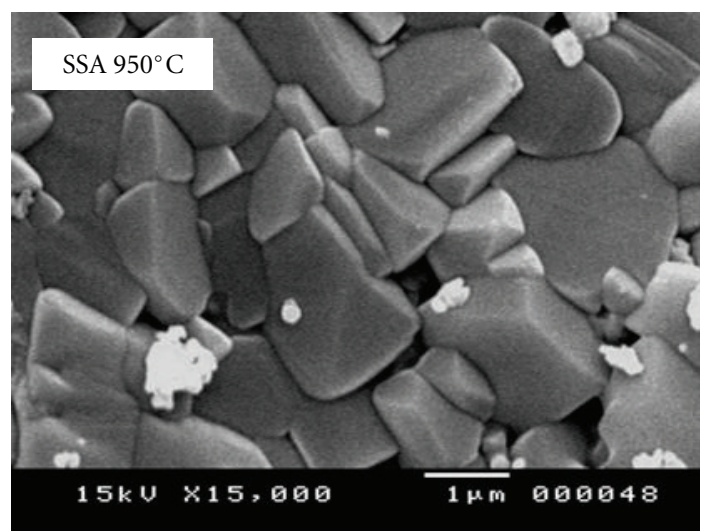

(d)

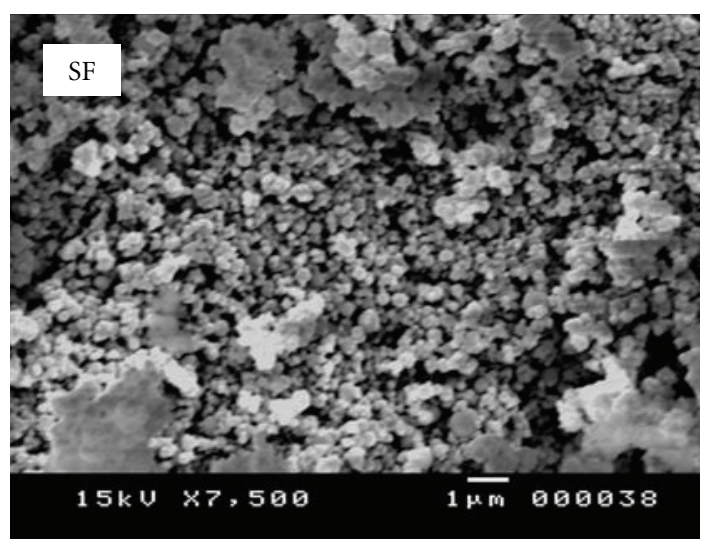

(e)

FIGURE 4: The SEM micrographs of silica fume, raw sewage sludge, and sewage sludge incinerated at $500-950^{\circ} \mathrm{C}$.

TABLE 1: Chemical composition wt. $\%$ of sewage sludge ash incinerated at $800^{\circ} \mathrm{C}$ and silica fume determined by XRF analysis.

\begin{tabular}{lccccccccccc}
\hline Material & $\mathrm{SiO}_{2}$ & $\mathrm{Al}_{2} \mathrm{O}_{3}$ & $\mathrm{Fe}_{2} \mathrm{O}_{3}$ & $\mathrm{CaO}$ & $\mathrm{MgO}$ & $\mathrm{SO}_{3}$ & $\mathrm{Na}_{2} \mathrm{O}$ & $\mathrm{K}_{2} \mathrm{O}$ & LOI* $^{*} \mathrm{P}_{2} \mathrm{O}_{5}$ & $\mathrm{Total}$ \\
\hline Sewage sludge ash & 39.03 & 15.13 & 17.05 & 5.80 & 1.93 & 4.04 & 0.43 & 0.62 & 2.11 & 13.12 & 99.26 \\
Silica fume & 94.64 & 0.97 & 0.93 & 0.55 & 0.35 & 0.10 & 0.20 & 0.25 & 1.65 & 0.04 & 99.64 \\
\hline
\end{tabular}

${ }^{*}$ LOI is the loss on ignition. 


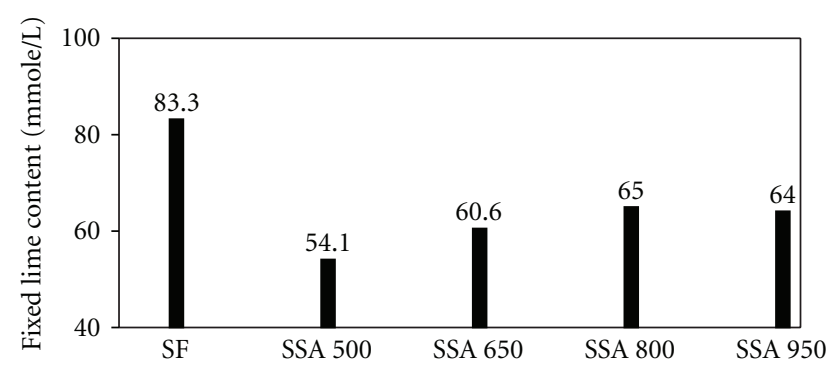

Figure 5: The fixed lime content of silica fume and sewage sludge incinerated at $500-950^{\circ} \mathrm{C}$ hydrothermally treated with lime at $100^{\circ} \mathrm{C}$ for $16 \mathrm{hrs}$.

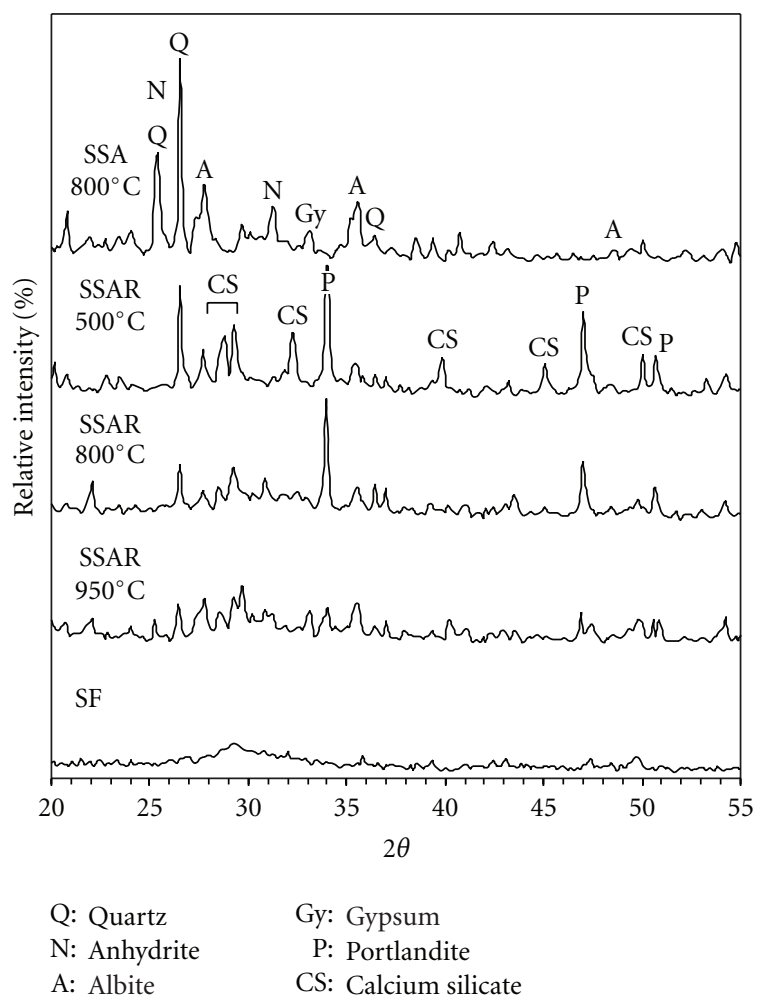

FIgUre 6: The XRD patterns of silica fume and sewage sludge incinerated at $500-950^{\circ} \mathrm{C}$ hydrothermally treated with lime at $100^{\circ} \mathrm{C}$ for $16 \mathrm{hrs}$.

$\mathrm{Ca}(\mathrm{OH})_{2}$ measured in absence (blank solution) and presence (sample solution) of sample [38].

X-ray fluorescence XRF and X-ray diffraction XRD analyses were carried out by Philips X-ray diffractometer PW 1370, Co. with Ni filtered $\mathrm{CuK}_{\alpha}$ radiation (1.5406 $\AA$ ). The Fourier transform infrared FTIR analysis was measured by spectrometer Perkin Elmer FTIR System Spectrum X in the range $400-4000 \mathrm{~cm}^{-1}$ with spectral resolution of $1 \mathrm{~cm}^{-1}$. Scanning electron microscopy SEM was investigated by JeolDsm 5400 LG apparatus. The thermogravimetric TGA and differential thermogravimetric analyses DTG were carried out with the aid of Shimadzu Corporation thermo analyzer with DTG-60H detector with $10^{\circ} \mathrm{C} / \mathrm{min}$ heating rate from room temperature up to $1000^{\circ} \mathrm{C}$, under nitrogen atmosphere

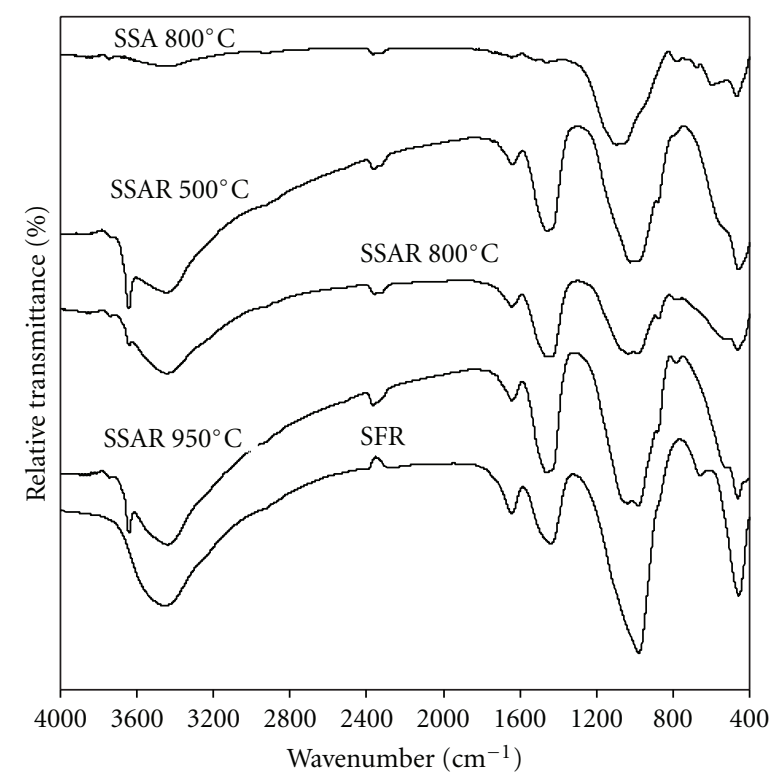

FIgURE 7: The FTIR spectra of silica fume and sewage sludge incinerated at $500-950^{\circ} \mathrm{C}$ hydrothermally treated with lime at $100^{\circ} \mathrm{C}$ for $16 \mathrm{hrs}$.

at $40 \mathrm{~mL} / \mathrm{min}$ flow rate, the hold time at the appropriate temperature is zero.

\section{Results and Discussion}

3.1. Characterization of Sewage Sludge Ash. Table 1 illustrates the chemical composition of sewage sludge ash incinerated at $800^{\circ} \mathrm{C}$ and silica fume determined by XRF analysis. The sum of $\mathrm{SiO}_{2}, \mathrm{Al}_{2} \mathrm{O}_{3}$, and $\mathrm{Fe}_{2} \mathrm{O}_{3}$ content in sewage sludge ash is higher than requirements stated in ASTM designation for natural pozzolana [39]. Sewage sludge ash has high $\mathrm{Al}_{2} \mathrm{O}_{3}$, $\mathrm{Fe}_{2} \mathrm{O}_{3}$ and $\mathrm{CaO}$ contents due to the use of alum, ferric salts, and lime in wastewater treatment. High percentage of $\mathrm{P}_{2} \mathrm{O}_{5}$ is possibly due to domestic detergents. LOI is possibly due to incomplete incineration and adsorbed water. Silica fume is composed mainly of $\mathrm{SiO}_{2}$.

Figure 1 illustrates the TGA and DTG thermograms of raw sewage sludge. Weight loss which occurs in temperature range $50-130^{\circ} \mathrm{C}$ is due to elimination of moisture and absorbed water. Weight losses which occur in temperature range $200-320^{\circ} \mathrm{C}$ and $330-390^{\circ} \mathrm{C}$ are due to emission of volatile organic matter and combustion of complex nonvolatile organic matter, respectively. This is because sewage sludge composes of various species of hydrocarbons with a wide range in boiling point [40]. Weight loss which occurs in temperature range $400-670^{\circ} \mathrm{C}$ is due to combustion of fixed carbon captured by inorganic materials, elimination of structural water of the clay mineral, and decomposition of the carbonaceous matter present in sewage sludge.

Figure 2 illustrates the XRD patterns of silica fume, raw sewage sludge, and sewage sludge incinerated at $500-950^{\circ} \mathrm{C}$. Raw sewage sludge contains quartz $\mathrm{SiO}_{2}$, anhydrite $\mathrm{CaSO}_{4}$, gypsum $\mathrm{CaSO}_{4} \cdot 2 \mathrm{H}_{2} \mathrm{O}$, and albite $\mathrm{NaCaSi}_{4} \mathrm{Al}_{4} \mathrm{O}_{8}$ minerals. Calcite $\mathrm{CaCO}_{3}$ appears after incineration of sewage sludge 


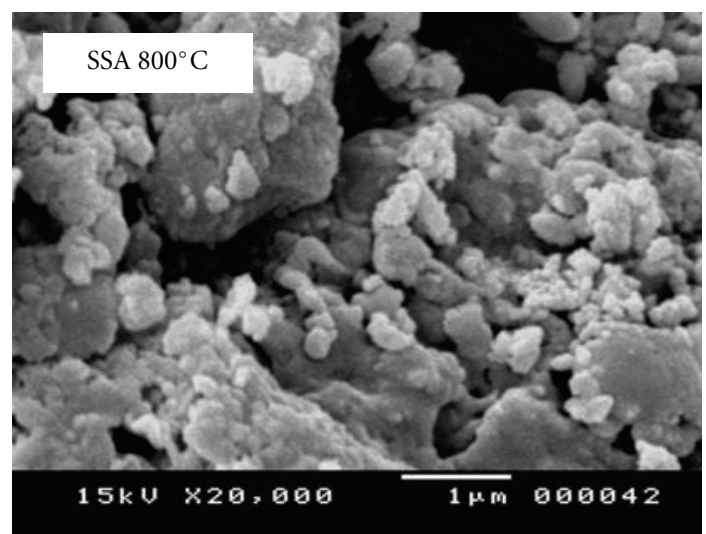

(a)

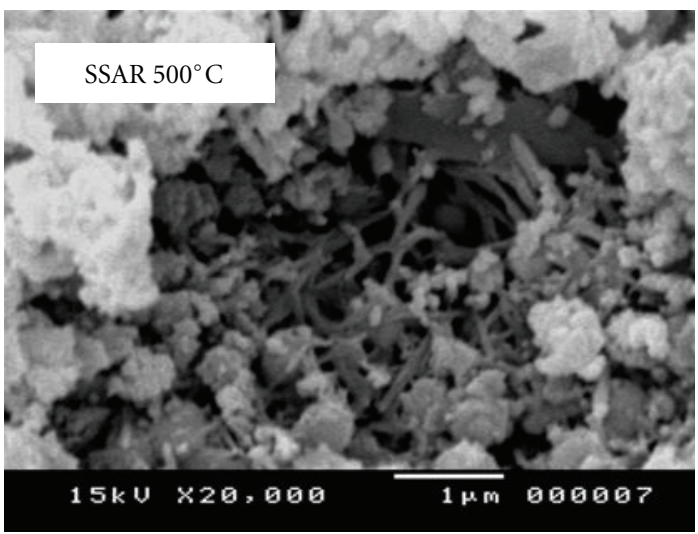

(c)

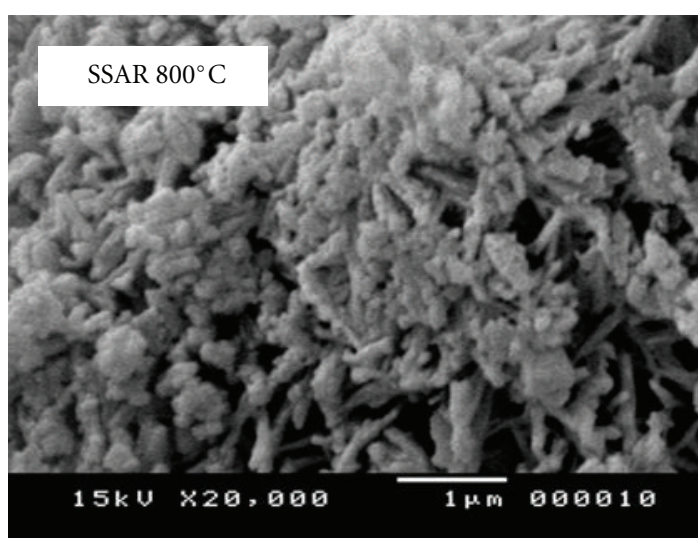

(b)

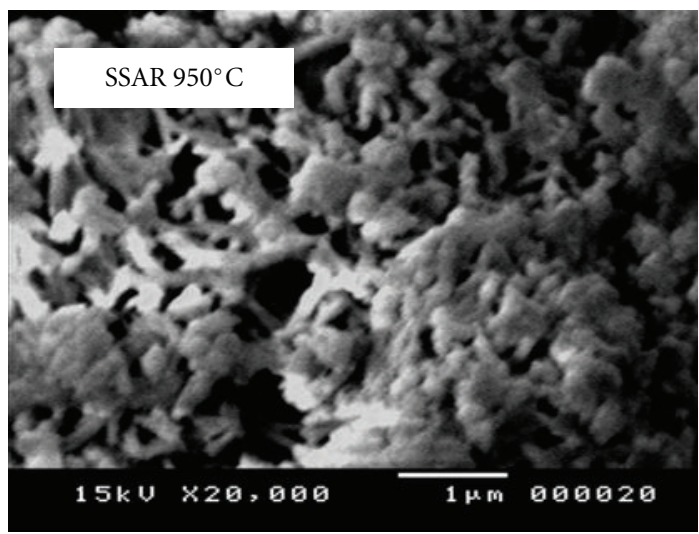

(d)

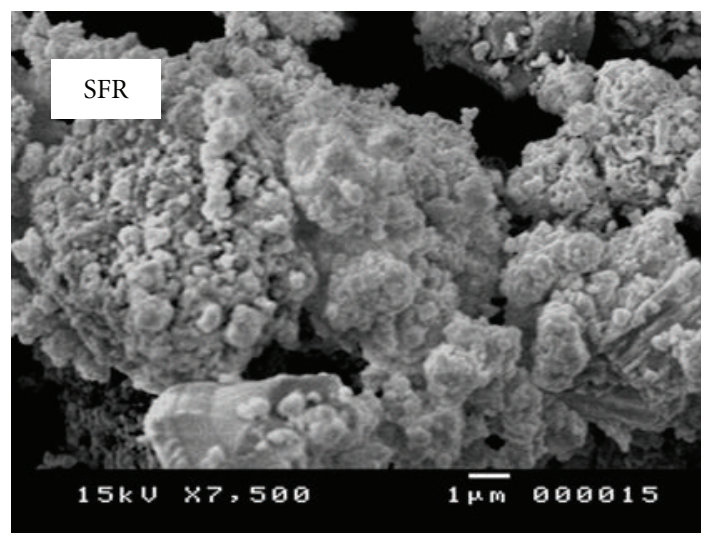

(e)

FIgURE 8: The SEM micrographs of silica fume and sewage sludge incinerated at $500-950^{\circ} \mathrm{C}$ hydrothermally treated with lime at $100^{\circ} \mathrm{C}$ for $16 \mathrm{hrs}$.

at $500^{\circ} \mathrm{C}$. This may be due to carbonation of some calcium compounds by $\mathrm{CO}_{2}$ produced from combustion of organic matter. After incineration of sewage sludge at 800 and $950^{\circ} \mathrm{C}$, calcite decomposes into calcium oxide $\mathrm{CaO}$. Hematite appears as a result of oxidation of iron compounds. Silica fume is composed mainly from amorphous silica as indicated from the heap in the range 15-3020.
Figure 3 illustrates the FTIR spectra of silica fume, raw sewage sludge, and sewage sludge incinerated at $500-950^{\circ} \mathrm{C}$. The absorption bands of organic matter appear at 681, 1200 and $1628 \mathrm{~cm}^{-1}$. The absorption band of P-containing compounds appears at $567 \mathrm{~cm}^{-1}$ due to $\mathrm{P}-\mathrm{O}$ bending vibration [41]. Silica absorption bands appear at 469, 785 and $1052 \mathrm{~cm}^{-1}$ [42]. The absorption band of carbonate appears at 
$1442 \mathrm{~cm}^{-1}$ [43]. After incineration at $500^{\circ} \mathrm{C}$, the absorption bands of organic matter disappear while that of carbonate appears due to carbonation of some calcium compounds by $\mathrm{CO}_{2}$ produced from incomplete combustion of organic matter as emphasized from XRD results. Incineration of sewage sludge at $800^{\circ} \mathrm{C}$ leads to a decrease in the intensity of the absorption bands of silica. This is an indication of increasing the degree of polymerization of silica network as a result of the crystallization of silica into quartz. The intensity of absorption bands of silica increases in case of sewage sludge incinerated at $950^{\circ} \mathrm{C}$. This indicates that incineration of sewage sludge at temperature higher than $800^{\circ} \mathrm{C}$ enhances the crystallization of amorphous silica and this may adversely affect the pozzolanic activity of the resultant ash. Silica fume has absorption bands of silica with high intensity. This proves that silica fume is composed mainly from amorphous silica as emphasized by XRD results.

Figure 4 illustrates the SEM micrographs of silica fume, raw sewage sludge and sewage sludge incinerated at 500$950^{\circ} \mathrm{C}$. The organic matters which appear as small aggregates in case of sewage sludge disappear after incineration at $500^{\circ} \mathrm{C}$, leaving behind inorganic matter which appear as whitish aggregates. Incineration of sewage sludge at $800^{\circ} \mathrm{C}$ preserves the amorphous nature of the resultant ash due to elimination of fixed carbon captured by silica. Incineration of sewage sludge at temperatures higher than $800^{\circ} \mathrm{C}$ enhances the crystallization of amorphous silica. Accordingly, the pozzolanic activity of incinerated sewage sludge may be reduced when sewage sludge incinerated at temperature higher than $800^{\circ} \mathrm{C}$. The SEM micrograph of silica fume illustrates that silica fume is mainly composed of amorphous micro silica particles with very high surface area compared with sewage sludge ash. This may prove that the pozzolanic activity of silica fume is higher than sewage sludge ash.

3.2. Pozzolanic Activity of Sewage Sludge Ash. Figure 5 illustrates the fixed lime content of silica fume and sewage sludge incinerated at $500-950^{\circ} \mathrm{C}$ hydrothermally treated with lime at $100^{\circ} \mathrm{C}$ for $16 \mathrm{hrs}$. The fixation of lime on sewage sludge ash may occur both by the pozzolanic activity and lime adsorption capacity. The fixed lime content varies with incineration temperature of sewage sludge. Incineration affects the microstructure and amorphous silica content of incinerated sewage sludge. The fixed lime content increases to maximum value at $800^{\circ} \mathrm{C}$ then slightly reduces at $950^{\circ} \mathrm{C}$. This indicates that incineration of sewage sludge at $800^{\circ} \mathrm{C}$ may be preferred to preserve the pozzolanic activity of the resultant ash. From economic point of view, it is recommended that incineration of sewage sludge at $800^{\circ} \mathrm{C}$ is better than at higher temperatures. Fixed lime content of silica fume is much higher than that of sewage sludge ash. This reflects the higher pozzolanic activity of silica fume which is composed of amorphous microsilica particles having very high surface area.

Figure 6 illustrates the XRD patterns of silica fume and sewage sludge incinerated at $500-950^{\circ} \mathrm{C}$ hydrothermally treated with lime at $100^{\circ} \mathrm{C}$ for $16 \mathrm{hrs}$. The amount of portlandite decreases to minimum after incineration of sewage sludge at $800^{\circ} \mathrm{C}$, then it increases after incineration at $950^{\circ} \mathrm{C}$. While that of calcium silicate varies in an opposite manner. This indicates that incineration of sewage sludge affects its pozzolanic activity. The pozzolanic activity was enhanced with incineration of sewage sludge at $800^{\circ} \mathrm{C}$. The pozzolanic activity of sewage sludge ash prepared at $950^{\circ} \mathrm{C}$ decreases may be due to increasing the degree of crystallization of amorphous silica as emphasized from FTIR and SEM results of sewage sludge ash (Figures 3 and 4). The portlandite was disappeared in case of silica fume hydrothermally treated with lime due to the high pozzolanic activity of silica fume when compared with sewage sludge ash.

Figure 7 illustrates the FTIR spectra of silica fume and sewage sludge incinerated at $500-950^{\circ} \mathrm{C}$ hydrothermally treated with lime at $100^{\circ} \mathrm{C}$ for $16 \mathrm{hrs}$. The absorption band of C-S-H appears at $970 \mathrm{~cm}^{-1}$ due to Si-O stretching vibration [44]. The absorption band at $3640 \mathrm{~cm}^{-1}$ due to portlandite decreases to minimum at $800^{\circ} \mathrm{C}$ then increases at $950^{\circ} \mathrm{C}$. This indicates that the pozzolanic activity of sewage sludge ash prepared at $800^{\circ} \mathrm{C}$ is higher than at higher temperatures as emphasized from XRD results (Figure 6). The absorption band of portlandite was completely disappeared in case of silica fume hydrothermally treated with lime due to its high pozzolanic activity when compared to sewage sludge ash. The absorption band of carbonate at $1463 \mathrm{~cm}^{-1}$ may be due to partial carbonation of portlandite by atmospheric $\mathrm{CO}_{2}$.

Figure 8 illustrates the SEM micrographs of silica fume and sewage sludge incinerated at $500-950^{\circ} \mathrm{C}$ hydrothermally treated with lime at $100^{\circ} \mathrm{C}$ for $16 \mathrm{hrs}$. The hydrothermal treatment of sewage sludge ash with lime leads to formation of fibrous hydration products. The density of fibers increases to maximum at $800^{\circ} \mathrm{C}$ then decreases after that. This result is in a good agreement with XRD and FTIR results. This emphasizes that incineration of sewage sludge at $800^{\circ} \mathrm{C}$ is preferred to preserve the pozzolanic activity of the resultant ash. The morphology of hydration products formed from the hydrothermal treatment of silica fume with lime is different than that formed by sewage sludge ash (i.e., amorphous not fibrous).

Figure 9 illustrates the TGA thermograms of silica fume and sewage sludge incinerated at $500-950^{\circ} \mathrm{C}$ hydrothermally treated with lime at $100^{\circ} \mathrm{C}$ for $16 \mathrm{hrs}$. Weight losses corresponding to the decomposition of $\mathrm{C}-\mathrm{S}-\mathrm{H}$ at $125-$ $350^{\circ} \mathrm{C}$ are different for all samples [45]. The descending order of these weight losses are silica fume $>$ sludge ash incinerated at $800^{\circ} \mathrm{C}>$ at $950^{\circ} \mathrm{C}>$ at $650^{\circ} \mathrm{C}$. This indicates that the pozzolanic activity of silica fume is much higher than sewage sludge ash because the former is mainly composed of very fine amorphous silica particles. Sewage sludge ash incinerated at $800^{\circ} \mathrm{C}$ has high pozzolanic activity and adsorption capacity compared to other sewage sludge ash samples. Incineration of sewage sludge up to $800^{\circ} \mathrm{C}$ activates the pozzolanicity of the resultant ash. Incineration of sewage sludge at higher temperature enhances the crystallization of amorphous silica and reduces the pozzolanic activity as well as the adsorption capacity of the resultant ash. 


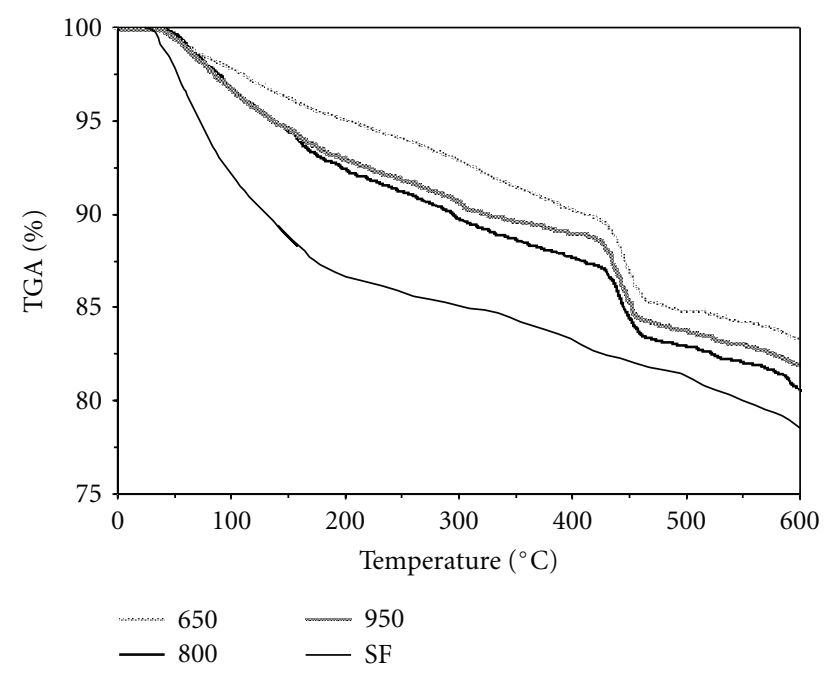

FIgURE 9: The TGA thermograms of silica fume and sewage sludge incinerated at $500-950^{\circ} \mathrm{C}$ hydrothermally treated with lime at $100^{\circ} \mathrm{C}$ for $16 \mathrm{hrs}$.

\section{Conclusions}

The main conclusions of this study are raw sewage sludge contains quartz, anhydrite, and albite minerals while silica fume contains amorphous micro silica. Incineration of sewage sludge at $500-950^{\circ} \mathrm{C}$ affects the microstructure and pozzolanic activity of the resultant ash. Incineration of sewage sludge at temperature lower than $800^{\circ} \mathrm{C}$ leads to a decrease in the pozzolanic activity of sewage sludge ash due to that amorphous silica captures fixed carbon resulting from incomplete combustion conditions. Incineration of sewage sludge at temperature higher than $800^{\circ} \mathrm{C}$ leads to a decrease in the pozzolanic activity of sewage sludge ash due to crystallization of amorphous silica. Hence, incineration of sewage sludge ash must be optimized at $800^{\circ} \mathrm{C}$ to preserve the pozzolanic activity of the resultant ash. Hydration products formed from hydrothermal treatment of silica fume with lime is amorphous whereas that of sewage sludge ash is fibrous.

\section{References}

[1] L. S. Clescerl, A. E. Greenberg, and A. D. Eaton, Standard Methods For Examination of Water and Wastewater, American Public Health Association, Washington, DC, USA, 20th edition, 1987.

[2] M. Eddy, Wastewater Engineering-Treatment, Disposal and Reuse, McGraw Hill, New York, NY, USA, 3rd edition, 1991.

[3] P. C. Hsiau and S. L. Lo, "Extractabilities of heavy metals in chemically-fixed sewage sludges," Journal of Hazardous Materials, vol. 58, no. 1-3, pp. 73-82, 1998.

[4] H. Ødegaard, B. Paulsrud, and I. Karlsson, "Wastewater sludge as a resource: sludge disposal strategies and corresponding treatment technologies aimed at sustainable handling of wastewater sludge," Water Science and Technology, vol. 46, no. 10, pp. 295-303, 2002.
[5] Y. J. Park and J. Heo, "Vitrification of fly ash from municipal solid waste incinerator," Journal of Hazardous Materials, vol. 91, no. 1-3, pp. 83-93, 2002.

[6] J. Casado-Vela, S. Sellés, J. Navarro et al., "Evaluation of composted sewage sludge as nutritional source for horticultural soils," Waste Management, vol. 26, no. 9, pp. 946-952, 2006.

[7] O. Malliou, M. Katsioti, A. Georgiadis, and A. Katsiri, "Properties of stabilized/solidified admixtures of cement and sewage sludge," Cement and Concrete Composites, vol. 29, no. 1, pp. 55-61, 2007.

[8] L. Feenestra, J. P. Brouwer, J. Frenay, and S. Bos, "Reuse of contaminated dredging sludge in a cement bound road base: full-scale demonstration project," in Proceedings of the 5TH International Conference on the Environmental and Technical Implications of Construction with Alternative Materials (Wascon'03), p. 593, Iscowa-Inasmet, San Sebastian, Spain, 2003.

[9] S. Valls, A. Yagüe, E. Vázquez, and C. Mariscal, "Physical and mechanical properties of concrete with added dry sludge from a sewage treatment plant," Cement and Concrete Research, vol. 34, no. 12, pp. 2203-2208, 2004.

[10] J. H. Tay, "Bricks manufactured from sludge," Journal of the Environmental Engineering Division, vol. 113, p. 270, 1987.

[11] R. B. Dean and M. J. Suess, "The risk to health of chemicals in sewage sludge applied to land," Waste Management and Research, vol. 3, no. 3, pp. 251-278, 1985.

[12] O. Malerius and J. Werther, "Modeling the adsorption of mercury in the flue gas of sewage sludge incineration," Chemical Engineering Journal, vol. 96, no. 1-3, pp. 197-205, 2003.

[13] O. Hjelmar, "Disposal strategies for municipal solid waste incineration residues," Journal of Hazardous Materials, vol. 47, no. 1-3, pp. 345-368, 1996.

[14] B. Khiari, F. Marias, F. Zagrouba, and J. Vaxelaire, "Analytical study of the pyrolysis process in a wastewater treatment pilot station," Desalination, vol. 167, no. 1-3, pp. 39-47, 2004.

[15] P. M. Bierman and C. J. Rosen, "Phosphate and trace metal availability from sewage-sludge incinerator ash," Journal of Environmental Quality, vol. 23, no. 4, pp. 822-830, 1994.

[16] M. T. Ali and W. F. Chang, "Strength properties of cementstabilized municipal solid waste incinerator ash masonry bricks," ACI Materials Journal, vol. 91, no. 3, pp. 256-263, 1994.

[17] J. Monzó, J. Paya, M. V. Borrachero, and A. Córcoles, "Use of sewage sludge ash(SSA)-cement admixtures in mortars," Cement and Concrete Research, vol. 26, no. 9, pp. 1389-1398, 1996.

[18] J. H. Tay, W. K. Yip, and K. Y. Show, "Clay-blended sludge as lightweight aggregate concrete material," Journal of Environmental Engineering, vol. 117, no. 6, pp. 834-844, 1991.

[19] M. Anderson, R. G. Skerratt, J. P. Thomas, and S. D. Clay, "Case study involving using fluidised bed incinerator sludge ash as a partial clay substitute in brick manufacture," Water Science and Technology, vol. 34, no. 3-4, pp. 507-515, 1996.

[20] M. H. Al Sayed, I. M. Madany, and A. R. M. Buali, "Use of sewage sludge ash in asphaltic paving mixes in hot regions," Construction and Building Materials, vol. 9, no. 1, pp. 19-23, 1995.

[21] A. M. Dunster, "Incinerated sewage sludge ash (ISSA) in autoclaved aerated concrete (AAC)," Characterization of Mineral Wastes, Resources and Processing Technologies - Integrated Waste Management For the Production of Construction Material WRT 177/WR0115, 2007. 
[22] K. S. Wang, I. J. Chiou, C. H. Chen, and D. Wang, "Lightweight properties and pore structure of foamed material made from sewage sludge ash," Construction and Building Materials, vol. 19, no. 8, pp. 627-633, 2005.

[23] M. Devant, J. A. Cusidó, and C. Soriano, "Custom formulation of red ceramics with clay, sewage sludge and forest waste," Applied Clay Science, vol. 53, p. 669, 2011.

[24] J. R. Pan, C. Huang, J. J. Kuo, and S. H. Lin, "Recycling MSWI bottom and fly ash as raw materials for Portland cement," Waste Management, vol. 28, no. 7, pp. 1113-1118, 2008.

[25] L. Chen and D. F. Lin, "Stabilization treatment of soft subgrade soil by sewage sludge ash and cement," Journal of Hazardous Materials, vol. 162, no. 1, pp. 321-327, 2009.

[26] M. Cyr, M. Coutand, and P. Clastres, "Technological and environmental behavior of sewage sludge ash (SSA) in cementbased materials," Cement and Concrete Research, vol. 37, no. 8, pp. 1278-1289, 2007.

[27] H. S. Shi and L. L. Kan, "Leaching behavior of heavy metals from municipal solid wastes incineration (MSWI) fly ash used in concrete," Journal of Hazardous Materials, vol. 164, no. 2-3, pp. 750-754, 2009.

[28] J. Monzó, J. Payá, M. V. Borrachero, and E. Peris-Mora, "Mechanical behavior of mortars containing sewage sludge ash (SSA) and Portland cements with different tricalcium aluminate content," Cement and Concrete Research, vol. 29, no. 1, pp. 87-94, 1999.

[29] C. M. A. Fontes, M. C. Barbosa, R. D. T. Filho, and J. P. Goncalves, "Potentiality of sewage sludge ash as mineral additive in cement mortar and high performance concrete," in Proceedings of the International RILEM Conference on the Use of Recycled Materials in Buildings and Structures, p. 797, Barcelona, Spain, 2004.

[30] J. H. Tay and K. Y. Show, "Municipal wastewater sludge as cementitious and blended cement materials," Cement and Concrete Composites, vol. 16, no. 1, pp. 39-48, 1994.

[31] J. Payá, J. Monzó, M. V. Borrachero et al., "Advantages in the use of fly ashes in cements containing pozzolanic combustion residues: Silica fume, sewage sludge ash, spent fluidized bed catalyst and rice husk ash," Journal of Chemical Technology and Biotechnology, vol. 77, no. 3, pp. 331-335, 2002.

[32] K. S. Wang, Y. S. Chang, K. Lin, and Z. Q. Huang, "The sintering characteristics of incinerator residues form municipal sewage sludge," in Proceedings of the 9th Annual Meeting Sanitary Engineering, p. 211, Taipei, Taiwan, 1999.

[33] S. C. Pan, D. H. Tseng, C. C. Lee, and C. Lee, "Influence of the fineness of sewage sludge ash on the mortar properties," Cement and Concrete Research, vol. 33, no. 11, pp. 1749-1754, 2003.

[34] S. Donatello, A. Freeman-Pask, M. Tyrer, and C. R. Cheeseman, "Effect of milling and acid washing on the pozzolanic activity of incinerator sewage sludge ash," Cement and Concrete Composites, vol. 32, no. 1, pp. 54-61, 2010.

[35] C. H. Chen, I. J. Chiou, and K. S. Wang, "Sintering effect on cement bonded sewage sludge ash," Cement and Concrete Composites, vol. 28, no. 1, pp. 26-32, 2006.

[36] P. Garcés, M. Pérez Carrión, E. García-Alcocel, J. Payá, J. Monzó, and M. V. Borrachero, "Mechanical and physical properties of cement blended with sewage sludge ash," Waste Management, vol. 28, no. 12, pp. 2495-2502, 2008.

[37] D. H. Zeng, S. Z. Pan, and Li, "The study of the characteristics of sewage sludge ash and the development of reclamation techniques," in Proceedings of the 12th Annual Meeting Sanitary Engineering, p. 221, Taipei, Taiwan, 2002.
[38] T. Perraki, G. Kakali, and F. Kontoleon, "The effect of natural zeolites on the early hydration of Portland cement," Microporous and Mesoporous Materials, vol. 61, no. 1-3, pp. 205-212, 2003.

[39] ASTM designation, "Standard specification for coal fly ash and raw or calcined natural pozzolana for use as a mineral admixture in concrete," Annual Book of ASTM Standards C 618-89, 1998.

[40] T. Karayildirim, J. Yanik, M. Yuksel, and H. Bockhorn, "Characterisation of products from pyrolysis of waste sludges," Fuel, vol. 85, no. 10-11, pp. 1498-1508, 2006.

[41] R. Z. LeGeros and J. P. LeGeros, "Dense hydroxyapatite," in An Introduction To Bioceramics, L. L. Hench and J. Wilson, Eds., p. 139, World Scientific, Singapore, 1993.

[42] K. Baltakys, R. Jauberthie, R. Siauciunas, and R. Kaminskas, "Influence of modification of $\mathrm{SiO} 2$ on the formation of calcium silicate hydrate," Materials Science, vol. 25, no. 3, pp. 663-670, 2007.

[43] J. A. Gadsden, Infrared Spectra of Minerals and Related Inorganic Compounds, Butterworths, London, UK, 3rd edition, 1975.

[44] Y. Ping, R. J. Kirkpatrick, P. Brent, P. F. McMillan, and X. Cong, "Structure of calcium silicate hydrate (C-S-H): near-, mid-, and far-infrared spectroscopy," Journal of the American Ceramic Society, vol. 82, no. 3, pp. 742-748, 1999.

[45] J. Zhang and G. W. Scherer, "Comparison of methods for arresting hydration of cement," Cement and Concrete Research, vol. 41, no. 10, pp. 1024-1036, 2011. 

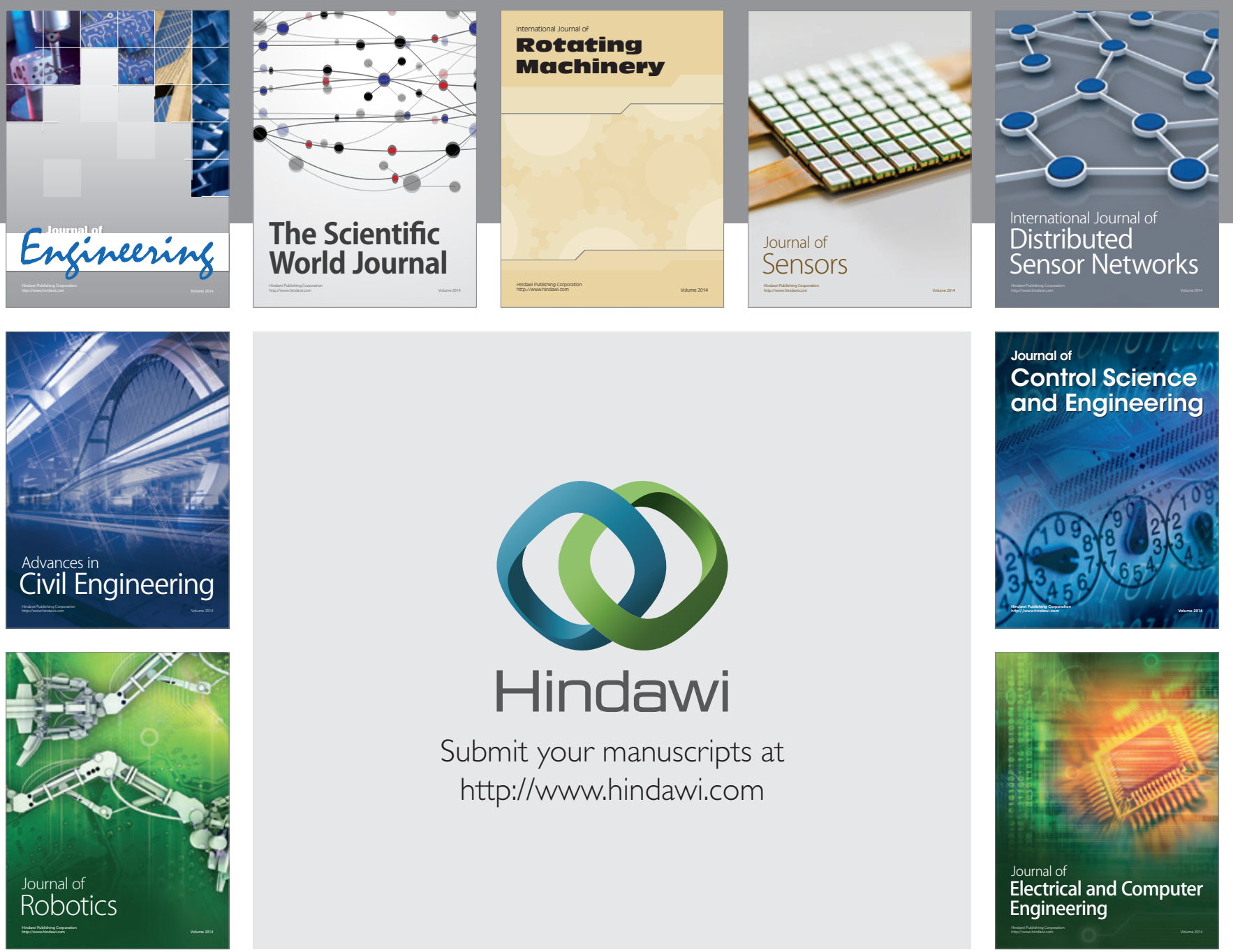

Submit your manuscripts at

http://www.hindawi.com
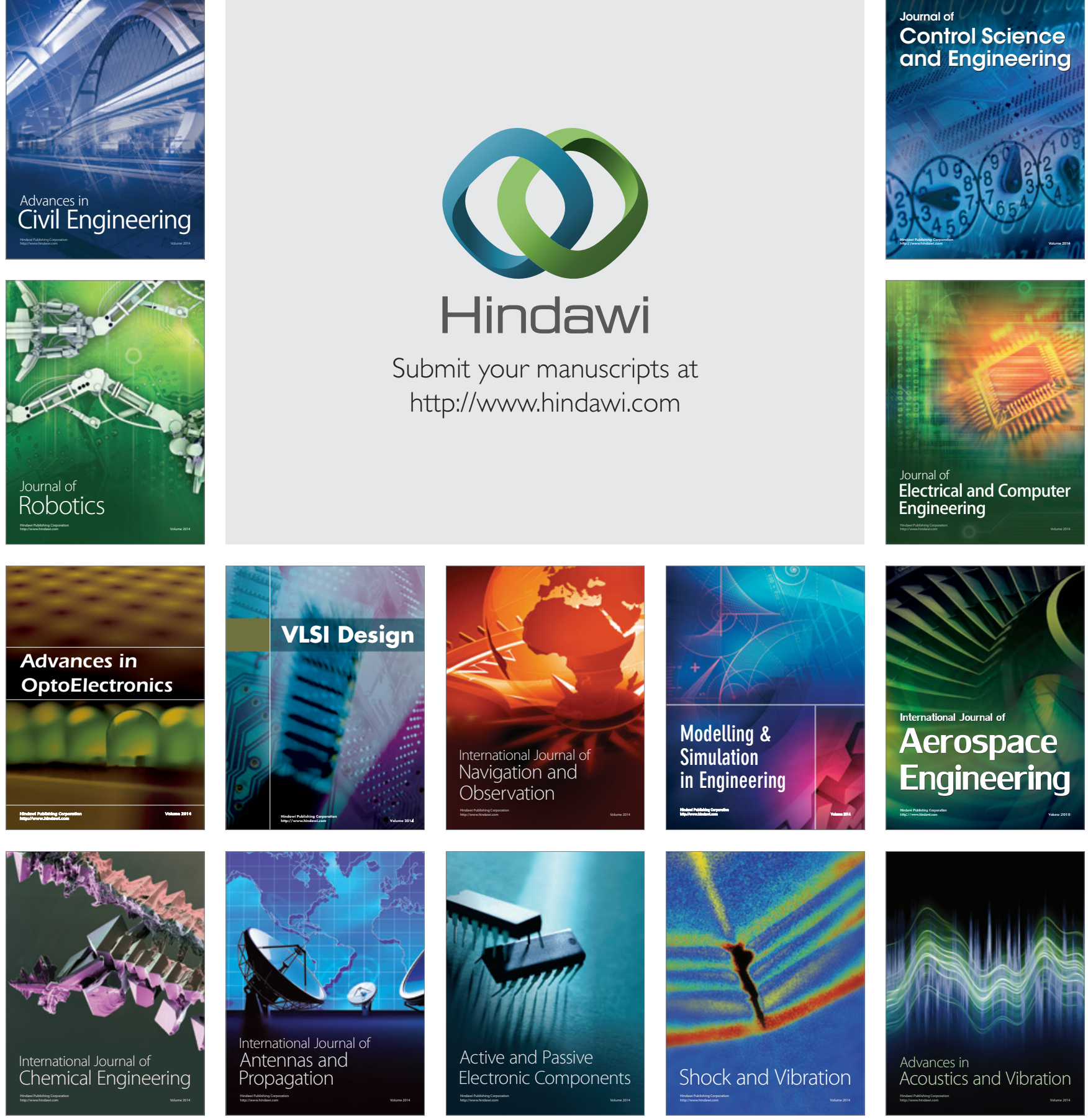